\title{
Less Drastic Means and the First Amendment
}

In deciding first amendment cases the Supreme Court has often used the phrase "less drastic means,"1 or words signifying the same thing, ${ }^{2}$ in finding that a governmental action has inhibited expression, belief, or association more than the Constitution allows. ${ }^{3}$ Similar language appearing in non-first amendment decisions has stood for the doctrine that the government, when it has available a variety of equally effective means to a given end, must choose the measure which least interferes with individual liberties. ${ }^{4}$ The Court has not made clear, however, what role the concept of less drastic means plays in first amendment jurisprudence. In fact, it often appears that invocation of the phrase "less drastic means" does not so much explain the result as announce it.

1. E.g., United States v. Robel, 389 U.S. 258, 268 (1967); Shclton v. Tucker, 364 U.S. $479,488(1960)$.

2. E.g., "Precision of regulation," NAACP v. Button, 371 U.S. 415, 498 (1963); "rcasonably drawn so that the precise evil is exposed," Schneider v. Smith, 390 U.S. 17, 24 (1968). Cases using this language are collected and described in Wormuth \& Merkin, The Doctrine of the Reasonable Alternative, 9 UTAн L. REv. 254, 267-93 (1964).

3. The determination of inhibitory effect on protected expression must be preceded by an analysis of the impact or coverage of a statute; the Court must first answer the question of what activity will be affected by enforcement of the statute. This Note ignores the manner in which that problem is resolved, and addresses itself only to the next step-whether any of the covered activity is protected by the first amcndmont.

For this latter issue vagueness and overbreadth are the same thing; both are objectionable because the legislation should have been drawn with more precision, or because a different policy could have been pursued.

Where statutes have an overbroad sweep, just as where they are too vague, . . those covered by the statute are bound to limit their behavior to that which is unquestionably safe.

Keyishian v. Board of Regents, 385 U.S. 589, 609 (1967).

The objectionable quality of vagueness and overbreadth does not depend upon absence of fair notice to a criminally accused or upon unchanneled clelegation of legislative powers, but upon the danger of tolerating, in the area of First Amend. ment freedoms, the existence of a penal statute susceptible of sweeping and improper application....

NAACP v. Button, 371 U.S. 415, 432-33 (1963). See also Elfbrandt v. Russell, 384 U.S. $11,19(1966)$. Both a too vague and an overly broad statute, then, infringe upon (or "chill") protected expression. Since such a statute has not adequately discriminated between protected and unprotected, a less drastic means must be used.

It should be emphasized that vagueness and overbreadth are equated only for determination of the "chilling effect." It is recognized that prior analysis of a statutc's coverage requires a distinction between those concepts. The impact of a vaguc statutc will usually be more difficult to determine than that of more precise legislation. $D u t ~ c /$. Speiser v. Randall, 357 U.S. 513 (1958), in which a quite specific statutory command was held to generate the fatal uncertainty normally associated with a vaguc statute.

4. E.g., Griswold v. Connecticut, 381 U.S. 479, 485 (1965) (right to privacy; see also Goldberg, J., concurring at 497-98, and White, J., at 503.04); Aptheker v. Sccretary of Stạte, 378 U.S. 500, 507-08 (1965) (right to travel); Dean Milk Co. v. City of Madison, 340 U.S. 349, 354 (1951) (legislation discriminating against interstate commerce). See also 
Recent pronouncements on the subject have only added more confusion. Justice Stewart's majority opinion in Shelton v. Tucker stated that "the breadth of legislative abridgement" in an Arkansas statute requiring public-school teachers to list all of their organizational affliations each year "must be viewed in light of less drastic means for achieving the same basic purpose," i.e., investigating the fitness and competence of public-school teachers. The opinion then went on to hold the requirement unconstitutional without mentioning a less drastic alternative, saying only that the interference with associational freedom was far greater than could be justified by the state's legitimate interest in its schools. ${ }^{-}$In United States $v$. Robel, ${ }^{8}$ decided last term, the Court denied that it could consider whether Congress's decision totally to ban Communists from employment in certain defense plants was the best of several alternatives to prevent sabotage. Though the Court insisted that analysis of alternative policies played no role in its decision to strike down the provision, ${ }^{10}$ the Justices were well aware that President Truman had urged Congress to retain then-existing, less drastic security measures-chiefly, investigation and screening programs-rather than ban Communists altogether."11

Shelton and Robel suggest that the rhetoric of less drastic means does not provide a trustworthy guide to what the Court is actually doing with the concept. Glearly, the Supreme Court can often decide cases which raise first amendment issues without appealing to less drastic means: the means which the legislature has selected may be

the concurring opinion of Justice Brennan in White Motor Co. v. United States, 372 U.S. 253, 271-72 (1963).

For a summary of the use of "less drastic means" doctrine in various arens of the law, see Wormuth \& Merkin, supra note 2. For analysis of its applicability to cases lawv, see Wormuthing economic regulation attacked under the duc process clause, sce Strurc, The Less-Restrictive Alternative Principle and Economic Due Process, 80 Hanv. L. REv. 1463 (1967).

5. 364 U.S. 479 (1960).

6. Id. at 488 .

7. Id. at 490 .

8. 389 U.S. 258 (1967).

9. It is not our function to examine the validity of . . . congressional judgment. exceeded the bounds imposed by the Constitution when First Amendment rights are at stake. The task of writing legislation has been committed to Congress. Our decision today simply recognizes that, when legitimate legislative concerns are at stake. The task of writing legislation has been committed to Congress. . . Amendment activities, Congress must achieve its goal by incans which have a "Iess drastic" impact on the continued vitality of First Amendment frecdoms.

389 U.S. at 267-68 (1967).

10. See note 9 supra.

11. See 389 U.S. at 267 (majority opinion); id. at 271 n.3 (Brennan, J., concurring). 
absolutely forbidden (for example, a bill of attainer ${ }^{12}$ ); the end which it seeks may be beyond its power ${ }^{13}$ or too insubstantial to justify any infringement on individual liberties, whether or not preferred; ${ }^{14}$ finally, the expression involved might be of a type which the Court has already determined to be protected, ${ }^{15}$ leaving only the task of deciding that an abridgement has occurred. In any of these cases the presence of less drastic means is irrelevant to the constitutionality of the measure that the legislature has adopted.

Most first amendment cases, however, rest on a balancing of the conflicting values and interests, whatever the Supreme Court calls the process. ${ }^{16}$ While the Court could formulate a balancing test that did

12. E.g., United States v. Brown, 381 U.S. 437 (1965); United States v. Lovett, 828 U.S. 303 (1946). The problem of identifying any particular statute as a bill of attainder, ex post facto law, law respecting the establishment of religion, etc., remains. Compare the above cases with American Communications Ass'n v. Douds, 339 U.S. 382 (1950).

13. E.g., a law denying to women the right to vote. But legislative power over the goal of a statute is rarely in question; the following statement from Dehnis v. Unitcd States, 341 U.S. 494 (1951), suggests the normal issue in a First Amendment case:

The question with which we are concerned here is not whether Congress has such power, but whether the means which it has employed conflict with the First and Fifth Amendments to the Constitution. Id. at 501 .

14. A court might decide that for certain evils, such as littering, disloyalty to the American system, or perverse sexual acts between consenting adults, any attempt to punish or regulate is unjustified. The fact that expression, rather than somcthing less important, is being inhibited is irrelevant; the evil has been classificd as per se insub. stantial. Very few statutes will meet this test of absolute insubstantiality; even littering could become a grave danger to community health. The Supreme Court has never been willing to tell Congress or a state legislature that its concerns were absolutely trivial. Many cases, however, hold that the State interest in enforcing a statute is insubstantial in relation to the inhibitory effect on expression. The dangers of littering and fraud that exist when handbills are distributed on the street, Schneider v. State (City of Irvington), 308 U.S. 147 (1939), the necessity for undoubted loyalty to the government in public teachers, Keyishian v. Board of Regents, 385 U.S. 589 (1967), a requirement that the NAACP submit membership lists for local tax records, Bates $v$. City of Little Rock, 361 U.S. 516 (1960), or for business registration purposes, NAACP v. Alabama, 857 U.S. 449 (1958), are a few examples of states' interests which have been found insubstantial only in relation to the effect of the regulation on expression. While the Court may be ready to forge a per se rule that some of these interests are trivial (e.g., loyalty) it has not yet done so. The decision in each of these cases clearly depended on the effect of the regu. lations upon expression.

15. Examples of "types" of speech are: political, inciting, literary, obscene and commercial. A classifier can refine these categories as much as necessary to make his per so rules of absolute protection do what he wants.

16. E.g., O'Brien v. United States, 391 U.S. 367, 377 (1968):

- we think it clear that a government regulation is sufficiently justified if it is within the constitutional power of the Government; if it furthers an important or substantial governmental interest; if the governmental interest is unrelated to the suppression of free expression; and if the incidental restriction on alleged First Amendment freedom is no greater than is essential to the furtherance of that interest ...; ;

Cox v. Louisiana, 379 U.S. 536, 577 (1965):

A state statute [regulating conduct with an incidental effect on expression] . . would be unconstitutional if under the circumstances it appearcd that the state's interest in suppressing the conduct was not sufficient to outweigh the individual's 
not include a comparison of alternative measures, ${ }^{17}$ such a test could not pretend to weigh the substantiality of the government's interest against the value of the affected first amendment freedoms. A scale which puts in one pan the public interest in some legitimate end of governmentnational security, civil peace, or preservation of the machinery of justice -rather than the interest in a particluar means to that end will rarely tip in favor of competing values. ${ }^{18}$ Since the Court has in fact allowed first amendment values to prevail even when the end pursued by the government was urgent, ${ }^{10}$ it must do its balancing at the margin-that

interest in engaging in conduct closely involving his First Amendment freedoms. (Black, J., concurring.)

Barenblatt v. United States, 360 U.S. 109, 126 (1959):

Where First Amendment rights are asserted to bar governmental interrogation resolution of the issue always involves a balancing by the courts of the competing private and public interests at stake in the particular circumstances shown ...;

Dennis v. United States, 341 U.S. 494, 510 (1951):

[The test is] whether the gravity of the "evil," discounted by its improbability. justifies such invasion of free speech as is necessary to avoid the danger.

(Vinson, C. J., quoting from lower court opinion, 183 F 2d 201, 212 (1950).)

There are two fundamental approaches to the first amendment: weighing and classifieation. Unless a judge takes the latter approach, the central core of any first amendment case is choosing between competing interests. Of course, many sorts of rules can govern the weighing process. The "clear and present danger" test, for example, imposes on weighing the requirement that the evil at which the statute is directed be very serious and the probability that it will occur if expression is unrepressed be very high. In practice, such a test differs from one which merely requires a reasonable probability and a legitimate state objective. But at the core of both tests is the weighing of state interest against first amendment interest, and it to that core that "less drastic means" is relevant.

On the other hand, the distinction between weighing and classification is not always clear. In order to determine which categories of expression deserve absolute protection. or which ends and means should be absolutely forbidden the legislature, the classifier must weigh the interests which are in conflict. Once this weighing has occurred, however, a judge is no longer required to reconsider competing interests case by case, but has only to examine the expression in each new case to discover whether it fits into the category for which a per se rule has been established. Mr. Justice Black, for example, believes that weighing of the dangers of unfettered specch against its value was carried out by the drafters of the Constitution, and that the result, a per se rule, is the first amendment. See Black, The Bill of Rights, 35 N.Y.U.L. REv. 865, 879 (1960). See generally Barenblatt v. United States, 360 U.S. 134, I43 (1959) (dissent); Konisberg v. State Bar of California 366 U.S. 36, 56, 61 (1961) (dissent). But not all expression fits within his per se rule. Cox v. Louisiana, 379 U.S. 536, 577 (1965) (concurrence) (where infringement is indirect, test is case-by-case balancing); Adderly v. Florida, 385 U.S. 39 (1966) (when demonstrators assemble on jailhouse grounds, they are no longer protected by the first amendment if prosecuted for trespassing).

Other Justices show much more flexibility in deciding whether to apply a categorical label to a particular statute. Compare American Communications Ass'n y. Douds, 339 U.S. 382 (1950), with United States v. Brown, 381 U.S. 437 (1965). The importance of distinguishing between classifying and weighing in $a$ given case is that the concept of less drastic means is useful only to a court willing to weigh competing interests.

17. Such a test appears to have been used in Communist Party v. Subicrsive Activities Control Board, 367 U.S. 1 (1961), and Barenblatt v. United States, 360 U.S. 109 (1959).

18. See T. EMIERSON, Toward A GeNERAL ThEORY OF THE FLRST AMENDMENT 55 (1963); Frantz, The First Amendment in the Balance, 71 Yale L.J. 1424, 1438-39 (1962).

19. Consider almost any case the government has lost. The state interest will nearly always be urgent and impressive if viewed alone. But the danger of riot which exists while an agitator is speaking will usually be lessened if numerous police mingle with 
is, it must balance no more than the state's interest in the added effectiveness of the chosen means against the individual interest in the use of less drastic ones.

Thus, when the Supreme Court holds that excluding all Communists from defense facilities unconstitutionally stifles rights of association and freedom, ${ }^{20}$ it has almost certainly decided that the gain in these freedoms is worth whatever additional cost and risk inheres in a less mechanical screening process-not that the national security would never justify imposing such a burden on Party membership. ${ }^{21}$ Yet how carefully the Court determines and weighs the presence of less drastic means remains uncertain. In one sense, a less repressive or even non-repressive alternative is always available, provided that the government is willing to sacrifice effectiveness;"22 but if "less drastic means" made that the test, it would simply signal that the right in question had absolute protection. By some process or another, then, the Justices must estimate how much less effective various alternative means would be, how much more they would cost-not merely in terms of the resources they would require, but also in terms of their effects upon other, non-first amendment social values ${ }^{23}$-and measure against accompanying gains these losses to expression, association, and belief.

A precise evaluation of less drastic means is an uncommonly difficult task; and with respect to the first amendment it is fair to say that the

the crowd. So too will be the substantiality of the state's interest in preventing the agitator from speaking. Cf. Feiner v. New York, 340 U.S. 315, 331 (1951) (Black, J., dissenting). The danger of harmful effects on children of titillating literary materials and photographs is lessened by a law punishing those who give such materials to chll. dren. Butler v. Michigan, 352 U.S. 380,383 (1957). On the other hand, even the distribu. tion of handbills would get to be a serious problem if there were no other methods of controlling littering, libel, and fraud except the impernissible one of banning handbills. Cf. Talley v. California, 362 U.S. 60 (1960); Schneider v. State (Town of Irvington), 308 U.S. 147 (1939).

20. United States v. Robel, 389 U.S. 258 (1967).

21. See note 19 supra.

22. Theoretical justification for the assumption that less drastic mcans are always available is that the state has a choice of no law at all; the morc satisfying practical justification is that the cases expose no legislative goal that could be reached by only one policy.

23. By definition, the less drastic alternative will inhibit expression less than the policy embodied by the statute before the Court. But this gain in first ancndment freedom might be accompanied by a destructive effect on other social or personal values. For example, the alternative to a ban on inflammatory specch might bc an increase in the number of police at public meetings. Some would contend that hordes of policemen are as repugnant as limited prior restraints on speech. Or, the alternative to a ban on door-to-door solicitation could be a sign which warns away the unwanted, but authorizes visits by those solicitors the homeowner wishes to see. Cf. Martin v. Clty of Struthers, 319 U.S. 141 (1941). Some would find their aesthetic sensibilities offended by such a sign. Cf., e.g., Breard v. City of Alexandria, 341 U.S. 662, 640 (1951). 
Supreme Court has never attempted it..24 In some cases where the Court has seemingly relied upon the availability of alternate measures, the alternatives were so plainly equivalent in efficiency to those the legislature had chosen that no sophisticated balancing was necessary to reach the right result. Martin v. City of Struthers ${ }^{25}$ is arguably this kind of case: there the Supreme Court ruled a city ordinance banning all door-to-door solicitations too severe an obstacle to free expression, considering that the danger of fraud could "be so easily controlled by traditional legal methods ...."26 In such a situation, however, the Court does not really have to consider less drastic means at all. Any sensible construction of the first amendment would forbid a legislature to go out of its way to inhibit expression, either by design or accident, and the choice of the harsher of equally effective means suggests that suppression of speech was the legislature's real purpose from the start. In fact, Justice Black, writing for the majority in Martin, expressly concluded from the existence of the obviously effective alternatives that the legislative intent was to squelch pamphleteering. ${ }^{2 \pi}$

24. The closest that any Justice usually comes to analyzing alternative means in a first amendment case is an admission that such analysis is necessary.

Whenever the reasonableness and fairness of a measure are at issue-as they are in

every case in which this Court must apply the standard of reason and faimess,

with the appropriate scope to be given those concepts, in enforcing the Due Process

Clause of the Fourteenth Amendment as a limitation upon state action-the avail-

ability or unavailability of alternate methods of proceeding is germane.

Shelton v. Tucker, 364 U.S. 479, 493 (1960) (Frankfurter, J., dissenting). Some comparative findings were listed in the majority opinions in the Sunday Closing Cases, but there the statutes were upheld and the first amendment found not to apply. IIcGowan $v$. Maryland, 366 U.S. 420 (1961); Braunfeld v. Brown, 366 U.S. 599 (1961).

A flagrant example of the Court's refusal to take non-first amendment values into account occurs in United States v. Robel, 389 U.S. 258 (1967). The Court mentions an industrial screening program as a possible less drastic means; it would be hard to call that measure "less repressive" without considering the loss of privacy it involves for all potential defense plant workers. Cf. Schneider v. Smith, 390 U.S. 17 (1968), where the Court's opinion suggests that such a program might itsclf be unconstitutional. Compare the Court's opinion with the concurring opinion of Justice Fortas. Id. at 27-28.

25. 319 U.S. 141 (1941).

26. Id. at 147 .

27. The dangers of distribution can be so easily controlled by traditional legal methods ... that stringent prohibition can serve no purpose other than that forbidden by the constitution, the naked restriction of dissemination of idess.

319 U.S. at 147. This statement might suggest that the availability of less drastic means is evidence of illegitimate purpose on the part of a Iegislature. (Justice Frankfurter distinguished Martin on those grounds in his concurring opinion in Dennis $v$. United States, 341 U.S. 494,540 (1951)).

Such an interpretation leads to confusion. In order for legislative intent to form an independent basis for decisions, one must differentiate between the impact or effect of a statute, and the personal "motives" behind its passage. CJ. A. Bicrei, THE LEAST DANGEROUS BRANCH, 209-10 (1962). All would agree that the constitutionality of a statute can be decided by analyzing its effects; to call these effects the "dominant purpose" of the legislature adds nothing.

If, however, constitutionality depends on the motiz'c of a legivlature, the concept 
Another set of cases apparently evaluating less drastic means is those in which the challenged action contains its own less drastic means, such as a statutory provision that covers an easily identified group of individuals not presenting any substantial threat of the evil which prompted the government to act. Again, the Court does not have to face differences in cost and effectiveness between the chosen means and the less repressive alternative: the less drastic means is the same statute, written more narrowly. In United Public Workers $v$. Mitchell, ${ }^{38}$ for example, Justice Douglas argued in dissent that the Hatch Act could have exempted non-administrative government employees from its ban on participation in political activity without increasing the risk of an overly partisan civil service. ${ }^{29}$ Yet the Court may not need the concept of less drastic means to handle such cases either: due process is sufficient to strike down a statute that groundlessly restricts someone's freedom. ${ }^{30}$ Only if the government has some reason for sweeping wide ${ }^{31}$ must the Court return to the less drastic means test, with all its complex comparisons, to determine just how substantial is the state's interest in the claimed "overbreadth."

becomes significant. A decision resting only on motive is not permanent, as the Court recognized in United States v. O'Brien, 391 US 967, 384 (1968):

We decline to void essentially on the grounds that it is unwise legislation which Congress had the undoubted power to enact and which could be reenacted in its exact form if the same or another legislator made a "wiser" speech about it.

Legislative motive is probably a factor in any subjective process of cvaluating a statute; it is almost certainly an unarticulated factor in a close first amendment casc. Since courts have no idea how to define and or prove legislative motive, O'Bricn $v$. United States, 391 U.S. 367, 385-86 (1968), it is unlikely that a court will rely on it as the basis for decision. The hypothesis with which this footnote began-that the availability of less drastic means is evidence of illicit motive-would probably be better stated in reverse: the Court's suspicions about legislative motive will influcnce its determination of the reasonable availability of alternate means.

28. 330 U.S. 75 (1946).

29. Id. at 120-26. Justice Douglas indicated that "industrial" cmployecs posed no general threat to the civil service system. Specific abuses were conceivable, but these could be dealt with by specific regulations. In Keyishian v. Board of Regents, 985 U.S. 589 (1967), the Court criticized one section of the Feinberg Law for failing to discriml. nate between employees in "sensitive" versus "non-sensitive" positions in the public school system; disloyal employees in non-sensitive jobs presumably were not a danger to anyone. Id. at 607. In both of these cases the statute was separable at no cost to the state.

30. See Griswold v. Connecticut, 381 U.S. 479 (1965).

31. Where overbreadth involves anything but an easily identifiable class of persons, the cost of restricting a statute is usually greater than the cost of enforcing the overbrond legislation. In Keyishian, for example, the Court said that the Feinberg Law could only be enforced against those with "specific intent" to overthrow the government by force. 385 U.S. at 608 . To distinguish between those with specific intent and others would be more expensive in terms of enforcement resources than merely separating those in "sensitive" and "non-sensitive" positions. Other examples of similar statutes for which restricting coverage would increase cost include Aptheker v. Secretary of Statc, 378 U.S. 500 (1964) (law withholding passports from Communists but not requiring specific intent held overbroad), and Smith v. California, 361 U.S. 147 (1959) (law which punislied 
Faced with the task of analyzing a case in terms of less drastic means, the Supreme Court has apparently solved the problem of comparing cost and effectiveness by assuming it away. Not only does the Court fail to compare the governmental action at issue with others that could have been taken, but it also generally refuses to specify what other means it has in mind.32 Perhaps this reticence is due to the fear of giving an advisory opinion: once the Court has named a less drastic means, not to uphold it subsequently might be less than politic. Moreover, an articulated comparison of alternatives raises the danger that the state will use its superior fact-finding and publicity machinery to discredit the Court's decision.

Concern over rendering an advisory opinion does seem appropriate in a narrow class of cases; for most, the alternative means either will be traditional (and hence tested) legal methods, ${ }^{33}$ or will be a less repressive statute of the same design as the one at issue. Conceivably, however, an attack on a statute repressing first amendment liberties might argue that the government could have effectively employed a completely different measure; this alternative might raise constitutional questions other than those applicable to the statute before the Court. In Robel, for example, the Court at least hinted that an industrial screening program would be less drastic than a total ban on Communists in defense plants, ${ }^{34}$ while a later case implies that a too thorough screening program may itself violate constitutional rights of privacy. ${ }^{35}$ To balance loss in effectiveness and resources against gain in first amendment freedoms where the alternative is very dissimilar, the Court may also have to decide the constitutionality of the alternate means.

sale of obscene books without requiring proof that the seller had knowledge of obscene content held overbroad).

Furthermore, the belief that two measures are equally effective is rarely true. The overbreadth in Mitchell and Keyishian (see note 30 supra) covers emplojees whose threat to the state is slight, not null. If the evil being legislated against is urgent enough-as in a statute protecting national security-the government will argue that even a slight or remote danger justifies repression of the rights of expression for the class of persons who present the lesser threat.

32. See United States v. Robel, 389 U.S. 258 (1967); Shelton v. Tucker, 364 US. 479 (1960). In some cases where laws already existing are sufficient to contain the cvil toward which the more repressive measure is aimed, the Court will indicate what those laws are. See, e.g., Butler v. Michigan, 352 U.S. 380 (1957); cf. Martin v. City of Struthers, 319 U.S. 141 (1941); Schneider v. State (Town of Irvington), 308 U.S. 147 (1939), where the Court refers to "traditional legal methods."

33. See p. 472 infra.

34. United States v. Robel, 389 U.S. 258 (1967); see p. 465 supra.

35. Schneider v. Smith, 390 U.S. 17, 24-27 (1968). The Court suggested that requiring the plaintiff to list membership in 250 named organizations as part of a screening pro. gram for the Merchant Marine was invalid under Shelton v. Tucker, 364 U.S. 479 (1960). 
A much more likely explanation of the Court's failure to give careful analyses of alternate means is that it does not believe itself competent to do so. ${ }^{36}$ There are no committees to look into alternative measures for the Justices, no staff of specialists to interpret data; there are only the arguments of lawyers to show what the cost and effectiveness of other means would be. Instead of attempting to calculate differences in cost and effectiveness, the Court has usually limited its survey of less drastic measures to "traditional legal methods" and assumed, on the basis of society's long experience with them, that these methods would be reasonably effective, practical, and inoffensive ways by which the state could accomplish the ends it claimed to seek. Thus, libel suits and criminal prosecutions are less drastic means of preventing defamatory or fraudulent publications than enjoining the publisher from printing his newspaper ${ }^{38}$ or prohibiting a pamphleteer from distributing his leaflets; ${ }^{30}$ specific laws are less repressive than breach-of-the-peace statutes; ${ }^{40}$ requiring the government to look to the intent of a possible subversive is an alternative to banning all Communists from defense plants ${ }^{41}$ or public schools, ${ }^{42}$ punishing false advertising is less drastic than prohibiting unsigned handbills; ${ }^{\text {to }}$ and punishing fraudulent misrepresentation is preferable to requiring that union organizers register with state officials. ${ }^{44}$ Relying on the existence of familiar methods of dealing with certain types of problems, the Court can hold that the government has adopted overly repressive means with some confidence that it has not ventured onto a limb. In cases where traditional legal methods are not visible in the foreground, or where the statute cannot be narrowed on its face, the Court often uses some other-possibly concealed-route to its result: it questions

36. Presumably comparison of alternatives is not outside the Court's institutional power, since it does make value choices between different policies by weighing. If one accepts that weighing must involve consideration of alternate means for accomplishing the legislative goal, the only issue remaining is the degree to which the Court should seek information about efficiency and cost. For an argument that the Court has becn too timid, and that it should take evidence in the form of "legislative facts," sec Karot, Legislative Facts in Constitutional Litigation, 1960 Sup. CT. REv. 75.

37. E.g., Martin v. City of Struthers, 319 U.S. 141, 147 (1943). See also Schncider v. State, 308 U.S. 147 (1939).

38. Near v. Minnesota, 283 U.S. 697 (1931).

39. Talley v. California, 362 U.S. 60 (1960); Schneider v. State, 308 U.S. 147 (1999),

40. Cox v. Louisiana, 379 U.S. 536 (1965); Cantwell v. Connceticut, 310 U.S. 296 (19.10).

4l. United States v. Robel, 389 U.S. 258 (1967).

42. Keyishian v. Board of Regents, 385 U.S. 589, 606-10 (1966). See also IElfbrandt v. Russell, 384 U.S. 11 (1966).

43. Talley v. California, 362 U.S. 60 (1960).

44. Thomas v. Collins, 323 U.S. 516 (1944). 
the state's intent, ${ }^{45}$ it applies a per se rule of absolute protection, ${ }^{40}$ it caves in to its own version of political necessity, ${ }^{4 i}$ or it discovers that the first amendment does not apply to the situation at hand. ${ }^{48}$

All of these shortcuts around the complexities of an analysis of reasonable alternatives, while arguably justified in most cases where they have been taken, raise questions about judicial use of the concept. The presence of less drastic means language in opinions invites the government to show that it has already found other means unsuccessful, or that reasonably effective alternatives do not exist, $\$$ thereby preserving the Court to uphold actions without trying to weigh the absolute importance of the interest behind the state's abridgement of liberty. If Congress or the states take up the gauntlet less drastic means opinions appear to throw down and begin to write into the preambles of legislation essays on the unavailability of alternatives, the Court could find that invocation of traditional legal methods would no longer be enough.

The notion of less drastic means thus poses a dilemma for the Supreme Court. It cannot use a balancing test and ignore less repres-

45. Three cases involving the NAACP in southern states an be best understood by reference to governmental purpose in enforcing laws which are othervise valid. NAACP v. Button, 371 U.S. 415 (1962); Bates v. Little Rock, 361 U.S. 516 (1960); NAACP v. Alabama, 357 U.S. 449 (1958).

46. The Court in Robel explicitly denied that it was balancing competing interests. United States v. Robel, 389 U.S. 258, 268 n.20 (1967). The only remaining cxplanation is that "mere" membership is a per se protected associational right, and that repression of the associational rights of employees in non-sensitive positions is a means absolutely forbidden to Congress.

47. E.g., Communist Party v. Subversive Activities Control Board, 367 US. 1 (1961). Frantz criticizes Justice Frankfurter for not meeting the argument that the S.1CB was unnecessary in light of other security measures already in force. Franz. The First Amendment in the Balance, 71 Yale L.J. 1424, 1440 n.72 (1962) (ciling Z. Cilafee, TuE Blessistos OF LIBERTY 122-36 (1956), to prove that the SACB served no uscful function).

48. See Roth v. United States, 354 U.S. 476 (1957). Compare Adderly v. Florida, 385 U.S. 39 (1966) (demonstration on jailhouse grounds), with Cox v. Louisiana, 379 US. 536 (1965) (demonstration in streets near State Capitol), and Edwards v. South Carolina, 372 U.S. 229 (1963) (demonstration on State House grounds).

49. The federal government made this argument and lost in United States v. Robel. 389, 258, 267 (1967), as did South Carolina in Sherbert v. Verner, 374 U.S. 398, 407 (1963). (1963).

50. The free press-fair trial problem suggests an example. In Sheppard v. Maxwell, 384 U.S. 333 (1966), the Court lists seven policies, none of which places a direct restraint on the press, that should be used to insure that a recalcitrant press does not lessen the defendant's opportunity to get a fair trial. 384 U.S. at 358-63. In the trial of James Earl Ray, all of these measures seem inadequate to fully protect the defendant's right to an impartial jury and unprejudicial courtroom atmosphere. The trial judge recently cited for contempt two newsmen who printed details about Ray's confincment in viola. tion of a court order. N.Y. Times, Oct. 1, 1968, at 48, col. 1. In detemining the constitu. tionality of this restraint on the flow of information, a court willing to balance should decide whether prejudice incurred by news storics is more or less important than an unfettered courthouse press. The danger suggested here is that the court will be lulled into accepting the inadequacy of other means as conclusive and not realize the necessity for a choice between the competing values. 
sive ways to achieve the governmental goal unless it is willing to give the state interest overwhelming weight in the balance. ${ }^{51}$ On the other hand, the Court's implicit admission that it is not qualified to choose between various means, coupled with the deference that should be paid the legislature's choice, tends to vitiate any less drastic means test. Procedural devices, such as requiring the government to prove the absence of reasonable alternatives when it threatens a serious infringement of first amendment freedoms, might offer an escape in some cases, ${ }^{62}$ though it might also provide the Justices with arguments they could not readily assess. But unless the Court adopts a priori notions of what is and is not protected expression or forbidden means, each different case will require a new choice between the conflicting values of the state's interest and the first amendment values. Since the Court lacks the competency to measure the relative efficiency, cost, and repressive effect of alternative measures, consideration of less drastic means cannot provide any form or structure to this choice. The search for standards that will make the adjudicative process more explicable must go forward without the illusion that "less drastic means" gives the Court a useful tool in first amendment cases.

51. See p. 467 supra.

52. The suggestion that the burden is on the government to show lack of other available means was made most recently in Sherbert v. Verner, 374 U.S. 398, 407 (1963). See also Talley v. California, 362 U.S. 60, 66-67 (1960) (Harlan, J., concurring); Thorn. hill v. Alabama, 310 U.S. 88, 98 (1940). What this burden means is unclear, but it is conceivable that a court could rest its decision not on the availability of other means, but rather on the government's failure of proof. Such a holding would be less objection. able in terms of the separation of powers doctrine. 